\title{
PERBANDINGAN SEBELUM DAN SESUDAH ADANYA "PERATURAN PEMERINTAH NOMOR 46 TAHUN 2013” DAN PENGARUHNYA TERHADAP PAJAK PERUSAHAAN (STUDI KASUS PADA PT. DBL)
}

\author{
Siti Ratna Sari Dewi \\ Fakultas Ekonomi, Universitas Pamulang \\ dosen01077@unpam.ac.id
}

\begin{abstract}
The purpose of this study is to find out how much the amount of tax issued and whether there is a difference in the amount of tax issued by the company before and after the existence of "PP Number 46 year, 2013 and the influence of the PP Number 46 year 2013" with corporate tax. The nature of this research is qualitative research with a comparative method and descriptive analysis with a case study approach method. Data collection techniques carried out in this study are through primary data, namely data obtained directly from data sources where the research was carried out and secondary data namely data obtained from literature and books that have to do with the problem under study. Through analysis of qualitative descriptive data and quantitative data analysis this research was conducted. And the results of the study show the amount of tax issued before the existence of PP number 46 of 2013 shows no tax payable, whereas after the issuance of the latest regulations the amount of tax incurred has increased. So there are differences in the amount of tax payments incurred due to the issuance of the latest regulations and the influence of the latest regulations on corporate taxes.
\end{abstract}

Keywords: "PP number 46 of 2013", corporate tax

\section{PENDAHULUAN}

Perkembangan tingkat ekonomi yang dirasakan bangsa Indonesia mulai mengalami peningkatan, hal ini bisa dicermati dari berbagai segi, mulai dari keamanan Nasional, pembentukan pemerintahan yang bersih dan merakyat, serta pertumbuhan ekonomi. Efek dari perkembangan ekonomi Indonesia bisa dilihat dari menguatnya rupiah dengan Dollar Amerika, inflasi serta suku bunga yang perlahan menurun juga meningkatnya cadangan devisa. Ini semua tidak terlepas dari peran serta pemerintah untuk membentuk suasana yang aman dalam lingkungan bermasyarakat.

Namun dalam proses perjalanannya, membuat pemerintah mengharuskan menentukan aturan-aturan yang diperlukan demi kelancaran aktivitas dalam pemerintahan serta mensukseskan kegiatan pembangunan nasional. Di dalam 
APBN,menunjukkan besarnyaangka penerimaan dan besarnya angka pengeluaran yang digunakan oleh pemerintah untuk menjalankan kegiatankegiatannya.Sebagian besar dana APBD berasal dari Pajak, dapat dilihat pada tahun 2013 anggaran penerimann pajak sebesar Rp. 725,84 Trilliun jika di presentasikan sebesar 73,64\% dari keseluruhan penerimaan APBN tahun 2013. Dibandingkan dengan angka tahun 2009 sebesar Rp 726,278 triliun, angka tahun 2013 ini jauh lebih rendah.

Kurangnya kesadaran dan kepedulian masyarakat terutama para Wajib Pajak untuk dapat memenuhi kewajiban perpajakan mengakibatkan tidak tercapai rencana tersebut. Sebagai fungsi dari alat yang digunakan pemerintah untuk mencapai tujuan perolehan penerimaan baik langsung maupun tidak langsung, baik dari wajib pajak badan ataupun pribadi untuk membiayai biaya ruti, pembangunan nasional serta perekonomian negara, maka tidak jarang terjadi konflik antara masyarakat sebagai wajib pajak yang memiliki tunggakan pajak dengan pemerintah.Konflik ini biasanya terjadi dikarenakan pemerintah ingin memungut pajak setinggi mungkin sedangkan wajib pajak dalam hal ini manajemen yang melakukan pembayaran berkeinginan untuk membayar sekecil mungkin.

Peraturan pajak yang mengalami perubahan dari waktu ke waktu yang mengikuti perkembangan perekonomian negara membuat sistem perpajakan di Indonesia menjadi rumit. Karena pajak merupakan penyumbang terbesar bagi sumber penerimaan negara, dari itu pemerintah memandang pentingnya memperbaharui undang-undang maupun peraturan pemerintah tentang sistem perpajakan yang ada disesuaikan dengan perkembangan dan fenomena di masyarakat. Agar tidak berimbas pada rendahnya penerimaan negara dari bidang pajak maka perubahan yang terjadi atas undang-undang dan peraturan pemerintah tersebut harus diimbangi dengan pendampingan dan penyuluhan untuk mengurangi kekurang pemahaman di masyarkat.

Pada dasarnya, tujuan dari perubahan perundang-udangan perpajakan yaitu memberi kemudahan bagi masyarakat dalam melaksanaan pembayaran serta pelaporan pajak, efisien dalam segi waktu administrasi pelaporan dan 
pembayaran hingga terjaganya produktivitas penerimaan negara keadilan karena tarif dalam pengenaan pajak disesuaikan dengan kondisi. Serta memberi kepastian dan transparasi dalam hukum.

Perpajakan di Indonesia sendiri memiliki berbagai macam peraturan perpajakan yang telah modifikasikan baik dalam segi perundang-undangan maupun peraturan yang dikeluarkan oleh pemerintah yang berwenang didaerah tersebut. Dengan adanyaperundang-undangan maupun peraturan setiap WP pribadi maupun badan diharuskan memahami aturan yang berlaku. Namun, tidak banyak wajib pajak yang mendapat akses dalam memperoleh informasi dalam bidang perpajakan. Sehingga hanya sebagian wajib pajak yang dapat mengikuti pembaharuan didalam perpajakan.

Masalah tersebut semakin rumit setelah adanyatax reform pada tahun 1983.Dimana tax reform tersebut menghasilkan perubahan sistem dan mekanisme pemungutan pajak.Dimana bermulaofficial assessmentberubah keself assessment system, dimanaWP lah yang harus aktif dalam menjalankan kewajiban perpajakannya, dimulai mendaftarkan dirihingga melaporkan pajaknya dengan menggunakan SPT.Dalam buku Mardiasmo, Gunadi berkata "ini dianggap sebagai penghambat, mengingat untuk mendukung penerapan self assessment system dengan baik, bermacam kebijakan dikeluarkan Dirjen Pajak dan Menteri Keuangan berdasarkan prinsip pemberlakuan hukum, dimana bila terdapat hukum bersifat khusus, maka hukum yang berlaku umum ditiadakan”. Maka dari itu, pengetahuan dalam bidang perpajakan harus mencukupi syarat utama yang harus dimiliki setiap WP sehingga dapat terpenuhi kewajiban pajaknya secara tepat dan terhindar dari segala sanski administrasi.

Untuk memudahkan proses pelaporam dan pembayaran maka dilakukan penyederhanaan dalam peraturan pajak terutama pajak penghasilan untuk WP dengan peredaran bruto tertentu adalah jawaban dari keluhan WP Pribadi dan Badan yang hingga saat ini sulit menghitung pajaknya. Dengan diberlakukannya "PP No 46 tahun 2013" diharapakan WP dapat menjalakan kewajibannya sebagai wajib pajak dengan mudah. 
Ruang lingkup yang termasuk kedalam Subjek Pajak dalam PP 46 ini sangat besar, sehingga masyarakat berkesempatan ikutberkontribusi dalam penyelenggaraan negara, dan kesempatan masyarakat untuk berkontribusi dalam penyelenggaraan negara pun meningkat, selain itukepatuhan sukarela dalam membayar pajak semakin tumbuh di masyarakat.Yang menjadi objek penghasilan bersifat final dalam PP 46 ini adalah penghasilan yang diterima atau diperoleh WP pribadi maupun WP Badan dengan peredaran bruto tidak melebihi Rp 4,8 miliar pertahun.

Penyederhanaan serta kemudahan dalam perhitungan PPh ini dikarenakan pemberlakuan tarif flat yaitu $1 \%$ dari peredaraan bruto usaha setiap bulannya. Dalarn rangka pelaksaan Undang-undang Pajak Pasal 9 "PP Nornor 46 Tahun 2013" tentang "Pajak Penghasilan atas Penghasilan dari Usaha yang Diterima atau Diperoleh Wajib Pajak yang Memiliki Peredaran Bruto Tertentu”, maka pemerintah perlu menetapkan "Peraturan Menteri Keuangan tentang Tata Cara Penghitungan, Penyetoran, dan Pelaporan Pajak Penghasilan atas Penghasilan dari Usaha yang Diterima atau Diperoleh Wajib Pajak yang Memiliki Peredaran Bruto Tertentu”.

Mengingat "Undang-undang nomor 6 tahun 1983" tentang “Ketentuan Umum dan Tata Cara Perpajak"dan mengalami perubahan beberapa kali terakhir dengan "Undang-undang nomor 16 tahun 2009", "Undang-undang nomor 7 tahun 1983" tentang “Pajak Penghasilan” yang telah mengalami perubahan beberapa kali dengan Undang-undang nomor 36 tahun 2008, Peraturan Pemerintah Nomor 94 tahun 2010 tentang "Perhitungan Penghasilan Kena Pajak dan Pelunasan Pajak Penghasilan dalam tahun berjalan" serta "Peraturan Pemerintah Nomor 46 tahun 2013" tentang "Pajak Penghasilan atas Penghasilan dari Usaha yang diterima atau Diperoleh Wajib Pajak yang memiliki peredaran bruto tertentu”. Maka dianggap perlu Menteri Keuangan mengeluarkan "Peraturan Menteri Keuangan Republik Indonesia Nomor 107/PMK.011/2013” tentang “Tata Cara Perhitungan, Penyetoran dan Pelaporan Penghasilan atas Penghasilan dari Usaha yang diterima atau diperoleh Wajib Pajak yang memiliki Peredaran Bruto tertentu”. 
Sehubungan dengan telah diterbitkannya "Peraturan Pemerintah Nomot 46 Tahun 2013” tentang "Pajak Penghasilan atas Penghasilan dari usaha yang diterima atau diperoleh Wajib Pajak yang memiliki Peredaran Bruto" dan Peraturan Menteri Keuangan Nomor 107/PMK.011/2013 tentang “Tata Cara Penghitungan, Penyetoran dan Pelaporan Pajak Penghasilan yang memiliki Peredaaran Bruto tertentu”, perlu dianggap perlu Direktur Jendaral Pajak mengeluarkan "Surat Edaran Direktur Jendral Pajak Nomor SE-42/PJ/2013" tentang "Pelaksanaan Peraturan Pemerintah Nomor 46 Tahun 2013 Tentang Pajak Penghasilan atas Penghasilan dari Usaha yang Diterima atau Diperoleh Wajib Pajak yang Memiliki Peredaran Bruto Tertentu” sebagai patokan WP dalam melaksanakan dan penerapan tarif pajak penghasilan bagi WP yang memiliki peredaran Bruto tertentu tersebut.

Dengan adanya SE Direktur Jendral Pajak ini berfungsi untuk memberikan acuan dalam pelaksanaa ketentuan Pajak Penghasilan bagi WP yang memiliki peredaran bruto tertentu. Penerbitan Surat Edaran ini juga bertujuan agar pelaksanaan ketentuan Pajak Penghasilan bagi Wajib Pajak yang memiliki peredaran bruto tertentu dapat berjalan dengan baik.

\section{METODOLOGI PENELITIAN}

Untuk mendapat data yang diperlukan, penulis melakukan penelitian di PT. DBL yang bertempat di Cilandak Town Square, Objek penelitian dilakukan terhadap bidang perpajakan yaitu $\mathrm{PPh}$ Final pasal 4 (2) dan Laporan Pendapatan Perusahaan.

Adapun penelitian dilakukan selama tahun pajak 2011 sampai dengan 2014. Pemilihan metodologi penelitian merupakan langkah yang harus dipikirkan dengan mempertimbangkan data, variabel-variabel penelitian dan metode pengumpulan data serta analisis yang dibutuhkan untuk masalah yang ada sehingga mendapat sebuah hasil penelitian.

Untuk menguji perbandingan sebelum dan sesudah adanya "Peraturan Pemerintah Nomor 46 Tahun 2013"penelitian ini menggunakan metode 
penelitian komparatif dengan studi kasus yang di ambil dari kasus pada PT. DBL.

\section{HASIL PENELITIAN DAN PEMBAHASAN}

\section{Gambaran Umum Objek Penelitian}

Di Indonesia, dengan mayoritas penduduk yang mencintai kuliner dan untuk memenuhi kebutuhan hasrat masyarakat yang cinta kuliner maka seorang kebangsaan Jerman Mr. Patrcik dengan istrinya yang berkebangsaan Indonesia membuka sebuah restoran bernuansa German bernama IS .

Sebagi satu-satunya di jantung kota Jakarta IS` sebagai restoran Jerman dengan pelayanan yang cepat dan memuaskan tujuan utamanya, dan untuk melayani pengunjung pada sebuah lingkungan keluarga yang merupakan tradisi dari keramahan bangsa Jerman. Keunggulan lain dari IS adalah menjadi satu-satunya Restaurant yang hanya menyajikan Bintang Draft Beer di seluruh Cilandak Town Square.

\section{- Visi dan Misi Perusahaan}

\section{Visi}

Menjadikan restoran yang berbeda dari yang lain dengan memiliki khas makanan German sebagai penyedia makanan yang berkualitas baik.

Misi

Dengan memberikan pelayanan yang baik dan memberikan rasa nyaman dengan membuat suasana restoran sebaik mungkin sehingga dapat menarik minat konsumen untuk terus datang kembali dan loyal terhadap restoran.

\section{- Struktur Organisasi Perusahaan}

Organisasi bertujuan untuk mencapai tujuan bersama yang belum bisa dicapai oleh para individu-individu itu sendiri.Dimana kelompok, dua orang atau lebih bekerjasama secara kooperatif dan koordinasikan dapat mencapai hasil lebih daripada dilakukan perseorangan. Agar tujuan 
perusahaan dapat tercapai diperlukan struktur organisasi yang berisi tentang penentuan kegiatan, pengelompokan tugas-tugas, penyerahan tugas-tugas pada bagian-bagian dan pendelegasian wewenang yang diperlukan untuk pelaksanaannya.

\section{Laporan Keuangan PT. DBL}

Penyusunan laporan keuangan berdasarkan prinsip-prinsip akuntansi yang berlaku secara umum sesuai dengan "Standar Akuntansi Keuangan (SAK)". Penyusuanan laporan keuangan memilikitujuan untuk menyediakan informasi keuangan yang bermanfaat bagi pihak-pihak yang berkepentingan seperti pemegang saham, investor, kreditor dan sebagainya. Dalam hal ini, laporan keuangan dapat digunakan sebagai bahan pertimbangan dalam pengambilan keputusan ekonomi dan kebijakan perusahaan untuk mencapai sasaran dan tujuannya secara relevan.

Kegiatan usaha yang bertujuan memperoleh laba mencangkup unsurunsur penghasilan, beban dan keuntungan (kerugian). Hal ini tercermin didalam laporan keuangan perusahaan yang dapat menyediakan informasi yang bermanfaat bagi berbagai pihak. Asumsi dasar yang digunakan perusahaan dalam menyelenggarakan pembukuaannya adalah dasar akrual (acrual basis), artinya penghasilan yang dilaporkan dalam laporan Laba Rugi merupakan penghasilan yang diakui selama periode akuntansi laporan Laba Rugi yang bersangkutan, dan pengaruh transaksi serta peristiwa lain diakui pada saat kejaian dan dicatat dalam catatan akuntansi serta disajikan dalam laporan keuangan periode yang bersangkutan.

Untuk memenuhi kewajiaban perpajakan, maka laporan keuangan harus dianalisis kembali serta disesuaikan dengan peraturan pajak yang berlaku sebagai dasar untuk menentukan besarnya pajak penghasilan PT. DBL. Laporan keuangan yang telah disusun belum tentu sesuai dengan laporan keuangan fiskal yang berdasarkan ketentuan perpajakan. Hal ini 
disebabkan adanya koreksi fiskal, baik koreksi fiskal positif maupun negatif atas perbedaan pengakuan pendapatan dan beban pada penyajian laporan keuangan perusahaan dan laporan keuangan secara perpajakan. Koreksi ini dimaksudkan untuk mengetahui jumlah Penghasilan Kena Pajak (PKP) atas laba komersil perusahaan yang menjadi dasar penghitungan $\mathrm{PPh}$ Badan yang terhutang dengan presentase tarif $\mathrm{PPh}$ badan yang berlaku.

Berikut ini Neraca dan Laporan Laba Rugi PT. DBL tahun 2011 hingga 2013.

a. Neraca PT. DBL Tahun 2011

\section{Tabel 4.1}

PT. DBL

N E R A C A

Per 31 Desember 2011

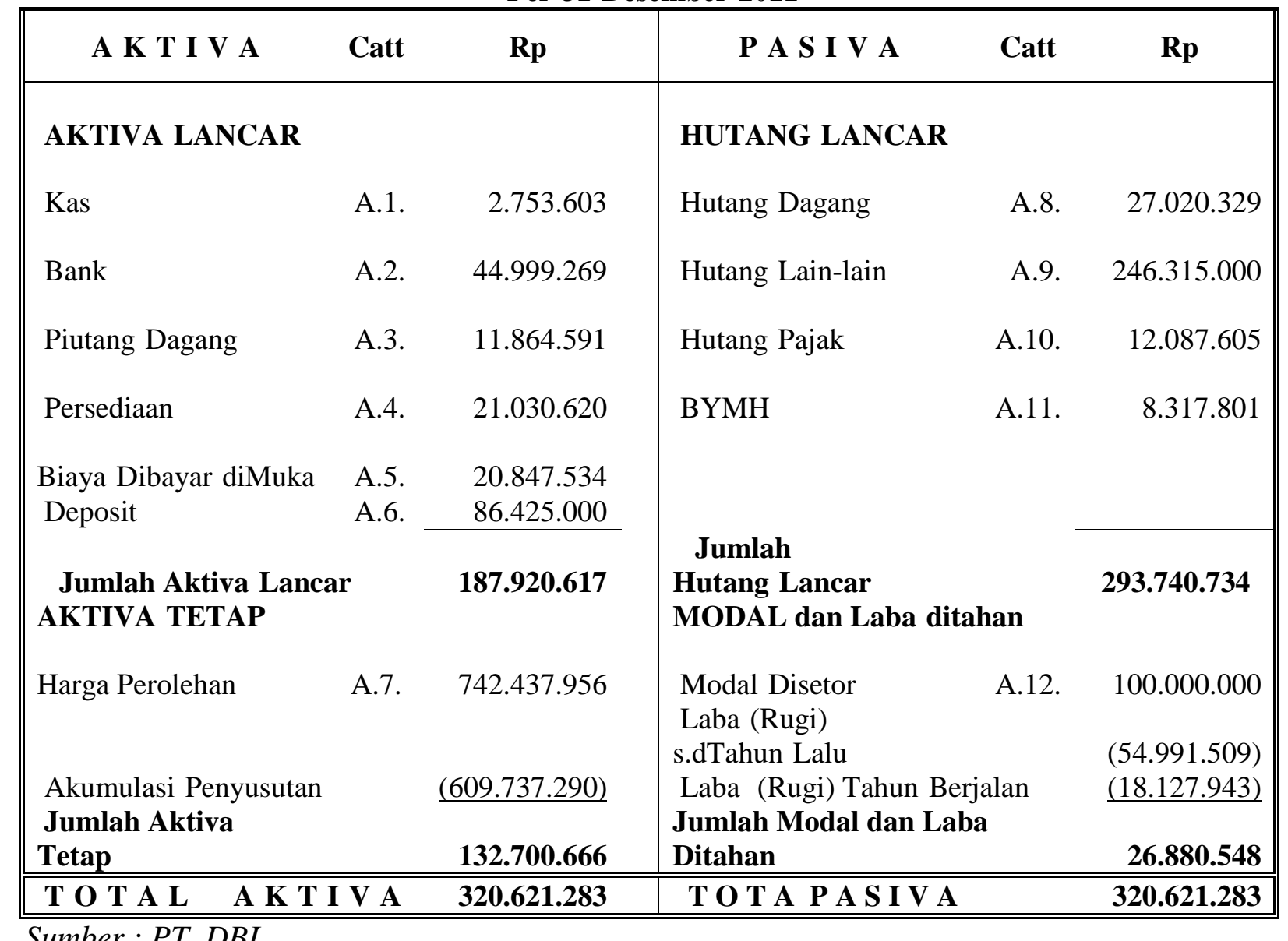


Dari tabel 4.1 diatas dapat terlihat posisi aktiva dan passiva PT. DBL selama Januari sampai dengan Desember tahun 2011.

b. Neraca PT. DBL Tahun 2012

Tabel 4.2

PT. DBL

N E R A C A

Per 31 Desember 2012

\begin{tabular}{|c|c|c|c|c|c|}
\hline A K T I V A & Catt & $\mathbf{R p}$ & P A S I V A & Catt & $\mathbf{R p}$ \\
\hline AKTIVA LANCAR & & & HUTANG LANC & & \\
\hline Kas & A.1. & 4.654 .521 & Hutang Usaha & A.8. & 287.816 .154 \\
\hline Bank & A.2. & 16.285 .225 & & & \\
\hline Piutang Dagang & A.3. & 13.588 .464 & Hutang Pajak & A.9. & 22.080 .117 \\
\hline Persediaan & A. 4 . & 21.661 .056 & & & \\
\hline Biaya Dibayar diMuka & A.5. & 140.170 .067 & BYMH & A.11. & 9.111 .425 \\
\hline Deposit & A.6. & 86.425 .000 & & & \\
\hline $\begin{array}{l}\text { Jumlah Aktiva Lancar } \\
\text { AKTIVA TETAP }\end{array}$ & & 282.784.333 & \multicolumn{2}{|c|}{$\begin{array}{l}\text { Jumlah } \\
\text { Hutang Lancar } \\
\text { MODAL dan Laba ditahan }\end{array}$} & 319.007 .696 \\
\hline $\begin{array}{l}\text { Harga Perolehan } \\
\text { Akumulasi Penyusutan }\end{array}$ & A.7. & 742.437 .956 & $\begin{array}{l}\text { Modal Disetor } \\
\text { Laba (Rugi) s.d } \\
\text { Tahun Lalu }\end{array}$ & A.12. & $\begin{array}{r}100.000 .000 \\
(39.555 .887)\end{array}$ \\
\hline Jumlah Aktiva Tetap & & 118.478.355 & $\begin{array}{l}\text { Laba (Rugi) Tahur } \\
\text { Jumlah Modal da } \\
\text { Ditahan }\end{array}$ & lan & $\begin{array}{l}\underline{21.810 .875} \\
\mathbf{8 2 . 2 5 4 . 9 8 8}\end{array}$ \\
\hline T O T A L A K T & $\mathbf{v}$ & 401.262.688 & $\begin{array}{l}\text { TOTAL } \\
\text { PASIVA }\end{array}$ & & 401.262.688 \\
\hline
\end{tabular}

Sumber : PT. DBL 
c. Neraca PT. DBL Tahun 2013

Tabel 4.3

PT. DBL

N E R A C A

Per 31 Desember 2013

\begin{tabular}{|c|c|c|c|c|c|}
\hline A K T I V A & $\overline{\text { Catt }}$ & $\overline{\mathbf{R p}}$ & PAS IVA & Catt & $\overline{\mathbf{R p}}$ \\
\hline \multicolumn{3}{|l|}{ AKTIVA LANCAR } & \multicolumn{3}{|c|}{ HUTANG LANCAR } \\
\hline Kas & A.1. & 1.114 .873 & \multirow[t]{2}{*}{ Hutang Usaha } & \multirow[t]{2}{*}{ A.8. } & \multirow[t]{2}{*}{215.533 .154} \\
\hline Bank & A. 2 . & 41.436 .251 & & & \\
\hline Piutang Dagang & A.3. & 15.588 .464 & \multirow[t]{2}{*}{ Hutang Pajak } & \multirow[t]{2}{*}{ A.9. } & \multirow[t]{2}{*}{14.973 .408} \\
\hline Persediaan & A. 4 . & 16.571 .397 & & & \\
\hline Biaya Dibayar diMuka & A.5. & 48.262 .500 & \multirow[t]{2}{*}{ BYMH } & \multirow[t]{2}{*}{ A. 10 . } & \multirow[t]{2}{*}{10.749 .328} \\
\hline Uang Muka Pajak & A. 6. & 637.974 & & & \\
\hline Deposit & A.7. & 86.425 .000 & \multirow{2}{*}{\multicolumn{2}{|c|}{$\begin{array}{l}\text { Jumlah } \\
\text { Hutang Lancar } \\
\text { MODAL dan Laba ditahan }\end{array}$}} & \\
\hline \multicolumn{2}{|l|}{$\begin{array}{l}\text { Jumlah Aktiva Lancar } \\
\text { AKTIVA TETAP }\end{array}$} & 210.036 .459 & & & 241.255.890 \\
\hline $\begin{array}{l}\text { Harga Perolehan } \\
\text { Akumulasi Penyusutan }\end{array}$ & A.7. & $\begin{array}{r}742.437 .956 \\
(639.005 .985)\end{array}$ & \multirow{3}{*}{\multicolumn{2}{|c|}{$\begin{array}{l}\text { Modal Disetor } \\
\text { Laba(Rugi) s.d } \\
\text { Tahun Lalu } \\
\text { Laba(Rugi) Tahun Berjalan } \\
\text { Jumlah Modal dan Laba } \\
\text { Ditahan }\end{array}$}} & $\begin{array}{l}100.000 .000 \\
(17.854 .387)\end{array}$ \\
\hline & & & & & 29.274 .628 \\
\hline \multicolumn{2}{|l|}{ Jumlah Aktiva Tetap } & 142.639 .676 & & & 111.420 .241 \\
\hline T O T A L & $\mathbf{A}$ & 352.676.135 & \multicolumn{2}{|c|}{ TOTA L PAS I } & 352.676 .135 \\
\hline
\end{tabular}

Sumber : PT. DBL

Dari tabel yang telah disajikan mulai dari tabel 4.1 sampai dengan 4. 3 dapat dilihat posisi aktiva dan pasiva perusahaan selama dari 2011, 2012 dan 2013 
Tabel 4.4

PT. DBL

Laporan Laba Rugi

Tahun 2011 sampai dengan 2013

\begin{tabular}{|c|c|c|c|c|}
\hline Keterangan & 2011 & 2012 & $\begin{array}{c}\text { Tidak Final } \\
\text { Jan-Juli } 2013\end{array}$ & $\begin{array}{c}\text { Final } \\
\text { Agust - Des } 2013\end{array}$ \\
\hline \multirow{2}{*}{$\begin{array}{l}\text { Penjualan } \\
\text { Harga Pokok Penjualan } \\
\text { Laba(Rugi) Kotor }\end{array}$} & $\begin{array}{l}\text { 1.237.500.000 } \\
(408.375 .000)\end{array}$ & $\begin{array}{l}\mathbf{1 . 5 7 7 . 4 0 1 . 5 6 4} \\
(195.583 .159)\end{array}$ & $\begin{array}{l}\mathbf{1 . 1 9 6 . 2 8 0 . 5 5 9} \\
(484.223 .500)\end{array}$ & $\begin{array}{r}\mathbf{6 6 3 . 7 9 3 . 8 6 5} \\
(198.583 .159)\end{array}$ \\
\hline & 829.125 .000 & 1.010 .230 .474 & 712.957 .059 & 465.219 .706 \\
\hline \multicolumn{5}{|l|}{ Biaya Operasional } \\
\hline Biaya Sewa Gedung & 363.510 .334 & 229.515 .000 & 229.515 .000 & 166.237 .500 \\
\hline Biaya Gaji Karyawan dan tunjangan & 298.890 .000 & 310.090 .350 & 310.090 .350 & 200.000 .000 \\
\hline PPh Pasal 21 & 4.591 .000 & 3.767 .684 & 3.767 .684 & 772.666 \\
\hline Biaya Listrik & 78.558 .692 & 62.655 .206 & 62.655 .206 & 58.641 .638 \\
\hline Biaya Air & & 4.666 .280 & 4.666 .280 & 3.265 .840 \\
\hline Biaya Jamsostek & - & 22.922 .100 & 16.045 .470 & 4.584 .420 \\
\hline Biaya Indovision & & & & \\
\hline \multirow{2}{*}{\multicolumn{5}{|c|}{ Biaya Hama }} \\
\hline & & & & \\
\hline Biaya Administrasi Bank & 5.052 .975 & 210.000 & 210.000 & 150.000 \\
\hline Biaya Administrasi Bank Card & - & 3.121 .168 & 3.121 .168 & 2.481 .998 \\
\hline Biaya Fotocopy dan Cetakan & 1.483 .100 & 1.611 .083 & 1.611 .083 & 322.217 \\
\hline Biaya Promosi Penjualan & - & & & \\
\hline Biaya Parkir dan Tol & - & 1.093 .333 & 1.093 .333 & 218.667 \\
\hline Biaya Keperluan Restoran & 1.577 .370 & 10.169 .152 & 10.169 .152 & 924.468 \\
\hline Biaya Keperluan Kantor & 10.253 .925 & 2.870 .167 & 2.870 .167 & 574.033 \\
\hline Biaya Keperluan Dapur & 4.125 .597 & & & \\
\hline Biaya Mesin EDC & 1.500 .000 & & & \\
\hline Biaya ATK & - & 1.034 .083 & 1.034 .083 & 206.817 \\
\hline Biaya Materai & - & 57.333 & 57.333 & 28.667 \\
\hline Biaya seragam & - & 480.000 & 480.000 & 240.000 \\
\hline Biaya Perijinnan & - & 4.166 .667 & 4.166 .667 & 833.333 \\
\hline Biaya Koran & - & 1.344 .045 & 1.344 .045 & 672.022 \\
\hline Biaya Pulsa & - & & & \\
\hline Biaya Entertaiment & & 2.537 .138 & 2.537 .138 & 845.713 \\
\hline Biaya Pengobatan & 268.830 & 991.466 & 991.466 & 330.489 \\
\hline Biaya Penyusutan & 154.388 .090 & 11.891 .206 & 11.891 .206 & 3.155 .178 \\
\hline Biaya Pemeliharaan Kendaraan & & 872.000 & 872.000 & 174.400 \\
\hline \multicolumn{5}{|l|}{ Biaya Pemeliharaan Inventaris Kantor } \\
\hline Biaya Pemeliharaan Dapur & & 1.316 .250 & 1.316 .250 & 263.250 \\
\hline Biaya Transportasi & 1.041 .950 & 4.750 .000 & 4.750 .000 & 950.000 \\
\hline Biaya Lain-lain & 1.139 .292 & 1.168 .029 & 1.168 .029 & 584.015 \\
\hline Total Biaya Operasional & $(847.748 .535)$ & $(948.978 .914)$ & $(687.035 .656)$ & (448.919.388) \\
\hline \multirow{2}{*}{$\begin{array}{l}\text { Laba(Rugi)Usaha } \\
\text { Pendapatan Lain-lain }\end{array}$} & $(\mathbf{1 8 . 6 2 3 . 5 3 5 )}$ & 25.125.599 & 25.021 .403 & 16.291.318 \\
\hline & 495.591 & 124.537 & 93.360 & 93.360 \\
\hline \multirow{2}{*}{$\begin{array}{l}\text { Biaya Lain-lain } \\
\text { Laba (Rugi) Bersih Sebelum Pajak }\end{array}$} & & (24.999) & (18.677) & (18.677) \\
\hline & $(\mathbf{1 8 . 1 2 7 . 9 4 3 )}$ & 25.403 .750 & 25.120 .941 & 16.366 .001 \\
\hline Laba (Rugi) Bersih Perusahaan & $(\mathbf{1 8 . 1 2 7 . 9 4 3 )}$ & 25.403 .750 & 25.120 .941 & 16.366 .001 \\
\hline
\end{tabular}

Sumber: PT. DBL

Sebagaimana telah disajikan dalam tabel tersebut di atas mengenai Laporan Laba/Rugi perusahaan selama tahun 2011-2013, pada tahun 2011 perusahaan mengalami kerugian sebesar ( $\mathrm{Rp} 18.127 .943,-)$, pada tahun 
2012 perusahaan memperoleh laba sebesar Rp. 21. 810.875,- dan pada tahun 2013 Januari sampai dengan Juli memperoleh laba sebesar Rp. 25.120.941 serta Agustus sampai dengan Desember 2013 sebesar Rp.16.366.001,--

\section{Beban Pajak Penghasilan Badan (Perusahaan)}

a. Perhitungan Pajak Penghasilan Badan Sebelum Adanya "Peraturan Pemerintah Nomor 46 Tahun 2013"

Dalam hal ini perusahaan harus melakukan rekonsiliasi untuk memperoleh beban pajak penghasilan perusahaan dengan cara koreksi positif dan koreksi negatif, laporan keuangan perusahaan dilihat pada tabel 4.4. Dari laporan keuangan pada tabel 4.4, untuk mengetahui pajak penghasilan badan maka dilakukan rekonsiliasi. berikut ini merupakan Laporan keuangan fiscal perusahan selama tiga tahun terakhir, pada tabel 4.5 untuk tahun tahun 2011, pada tabel 4.6 untuk tahun 2012 dan tahun 2013 disajikan dalam tabel 4.7 yaitu sebagai berikut:

1) Rekonsiliasi Fiskal Laporan Laba Rugi Sebelum Adannya "Peraturan Pemerintah Nomor 46 tahun 2013"

Ditemukan laporan laba rugi fiskal untuk tahun 2011, dan dapat dilihat bahwa perusahaan melakukan koreksi positif dan negative adapun unsur-unsur atau objek yang terkena koreksi fiskal adalah sebagai berikut:

a) Biaya PPh Pasal 21

PPh Pasal 21 yaitu pajak yang seharusnya menjadi tanggungan karyawan, namun PT. DBL untuk PPh Pasal 21 dibayar oleh perusahaan sendiri, tetapi tidak termasuk dalam tunjangan pajak sebagai tambahan penghasilan jadi terkena koreksi positif pada tahun 2011 Rp.4.591.000,- 
b) Biaya Pengobatan

Pengobatan yang dikeluaran oleh perusahaan dikoreksi positif pada tahun 2011 Rp. 222.750,-

c) Pendapatan Jasa Giro

Penghasilan dari jasa giro adalah penghasilan yang sudah dikenakan PPh Final, maka atas penghasilan tersebut harus dikoreksi fiskal negatif, dimana pada tahun 2011 Rp.495.591,-

Untuk tahun 2012, perusahaan melakukan koreksi positif dan negative adapun unsur-unsur atau objek yang terkena koreksi fiskal adalah seperti berikut:

a) Biaya PPh Pasal 21

Pajak Penghasilan Pasal 21 yaitu pajak yang seharusnya menjadi tanggungan karyawan, dalam hal ini PT. DBL untuk PPh Pasal 21 dibayar oleh perusahaan, tetapi tidak termasuk dalam tunjangan pajak sebagai tambahan penghasilan jadi terkena koreksi positif pada tahun 2012 Rp. 4.591.000,-

b) Biaya Jamsostek

Biaya Jamsostek yang dibayarkan oleh perusahaan untuk pegawai dikoreksi posotif pada tahun 2012 Rp. 20.238.480,-

c) Biaya Pulsa

Biaya Pulsa ini diberikan ke karyawan, biaya pulsa ini dapat dibayakan kelaporan keuangan fiskal hanya 50\%, dimana biaya pulsa tahun 2012 menjadi Rp. 275.000,-

d) Biaya Entertaiment

Biaya entertaiment ini berkaitan dengan pemberian kenikmatan kepada pihak ke tiga. Dalam hal ini biaya entertaiment dapat dibiayakan ke laporan keuangan fiskal jika disertai dengan bukti yang jelas dan dibuatkan daftar nominatif, tetapi perusahaan ini selama ini tidak memiliki bukti tersebut, jadi semua biaya tidak dapat dibiayakan dan dikoreksi fiskal positif, 
dimana tahun 2012 Rp.1.015.993,-

e) Biaya Lain-lain

Biaya lain-lain ini tidak dapat dibiayakan dalam laporan keuangan fiskal, karena tidak ada bukti pendukung dan keterangan yang jelas biaya tersebut untuk apa saja, makanya harus dikoreksi positif, dimana biaya pada tahun 2012 Rp.1.815.444,-

f) Pendapatan Jasa Giro

Penghasilan dari jasa giro adalah penghasilan yang sudah dikenakan PPh Final, maka atas penghasilan tersebut harus dikoreksi fiskal negatif, dimana pada tahun 2012 Rp.346.493,-

g) Biaya Pajak Jasa Giro

Pajak yang sudah dipotong oleh pihak bank merupakan Pajak Penghasilan bersifat Final, jadi atas biaya pajak jasa giro tersebut dikoreks positif dimana tahun 2012 Rp.69.302,-

Dari laporan laba rugi fiskal untuk tahun 2013, dan dapat dilihat bahwa perusahaan melakukan koreksi positif dan negative adapun unsur-unsur atau objek yang terkena koreksi fiskal adalah sepeti berikut:

a) Biaya PPh Pasal 21

Pajak Penghasilan Pasal 21 yaitu pajak yang seharusnya menjadi tanggungan karyawan, dalam hal ini PT. DBL untuk $\mathrm{PPh}$ Pasal 21 dibayar oleh perusahaan, tetapi tidak termasuk dalam tunjangan pajak sebagai tambahan penghasilan jadi terkena koreksi positif pada tahun 2013 Rp.16.045.470,-

b) Biaya Pengobatan

Pengobatan yang dikeluaran oleh perusahaan dikoreksi positif pada tahun 2013 Rp. 991.466,-

c) Biaya Entertaiment

Biaya entertaiment ini berkaitan dengan pemberian 
kenikmatan kepada pihak ke tiga. Dalam hal ini biaya entertaiment dapat dibiayakan ke laporan keuangan fiskal jika disertai dengan bukti yang jelas dan dibuatkan daftar nominatif, tetapi perusahaan ini selama ini tidak memiliki bukti tersebut, jadi semua biaya tidak dapat dibiayakan dan dikoreksi fiskal positif, dimana tahun $2013 \mathrm{Rp} .2 .537 .138,-$

d) Pendapatan Jasa Giro

Penghasilan dari jasa giro adalah penghasilan yang sudah dikenakan PPh Final, maka atas penghasilan tersebut harus dikoreksi fiskal negatif, dimana pada tahun 2013 Rp.124.537,-

e) Biaya Pajak Jasa Giro

Pajak yang sudah dipotong oleh pihak bank merupakan Pajak Penghasilan bersifat Final, jadi atas biaya pajak jasa giro tersebut dikoreks positif dimana tahun 2013 Rp.24.999,-.

Perhitungan Pajak Terhutang Sebelum Adanya PP Nomor 46 Tahun 2013

Setelah diketahui berapa besar jumlah koreksi positif dan negatif dan telah didapat laporan keuangan fiskal maka Berikut ini tabel 4.8-4.10 adalah perhitungan Pajak Penghasilan Badan tersebut selama tahun 2011 sampai dengan 2013, dimana tabel 4.8 untuk tahun 2011, 4.9 untuk tahun 2012, dan 4.10 untuk bulan Januari sampai juli tahun 2013 maka PPh Badan dapat dilihat sebagai berikut: 
Tabel 4.8

PT. DBL

Perhitungan PPh badan sebelum "46 th 2013 Tahun2011"

\begin{tabular}{|c|c|}
\hline Keterangan & $\mathbf{R p}$ \\
\hline Laba (Rugi) Komersial: & (18.127.943) \\
\hline \multicolumn{2}{|l|}{ Koreksi Positif(Negatif): } \\
\hline Jumlah Koreksi Positif & 4.813 .750 \\
\hline Jumlah Koreksi (Negatif) & $(495.591)$ \\
\hline Laba (Rugi) Pajak (DPP): & $(13,809.784)$ \\
\hline \multicolumn{2}{|l|}{ Kompensaasi Kerugian Fiskal : } \\
\hline Tahun 2010 & $(44.482 .154)$ \\
\hline Tidak Terhutang Pajak & (58.291.938) \\
\hline
\end{tabular}

Setelah mengetahui berapa jumlah koreksi positif dan jumlah koreksi negatif, hal selanjutnya ialah membuat perhitungan pajak penghasilan selama tahun 2011. Untuk mengetahui jumlah pajak tehutang dapat dilihat pada diatass, dari tabel diatas ini terlihat bahwa perusahaan selama tahun 2011 mengalami kerugian sebesar Rp.13.809.784,-. Karena mengalami kerugian ini maka perusahaan tidak terhutang pajak badan ditahun 2011. 
Tabel 4.9

PT. DBL

Perhitungan Pajak Penghasilan badan sebelum PP 462013

Tahun 2012

\begin{tabular}{|c|c|}
\hline Keterangan & $\mathbf{R p}$ \\
\hline Laba (Rugi) Komersial: & 25.528.750 \\
\hline \multicolumn{2}{|l|}{ Koreksi Positif (Negatif): } \\
\hline Jumlah Koreksi Positif & 28.005 .219 \\
\hline Jumlah Koreksi (Negatif) & $(346.493)$ \\
\hline Laba (Rugi) Pajak (DPP): & 53.187 .476 \\
\hline \multicolumn{2}{|l|}{ Kompensaasi Kerugian Fiskal : } \\
\hline \multicolumn{2}{|l|}{ Tahun 2008} \\
\hline \multicolumn{2}{|l|}{ Tahun 2009} \\
\hline \multicolumn{2}{|l|}{ Penghasilan Kena } \\
\hline \multicolumn{2}{|l|}{ Pajak(PKP) } \\
\hline \multicolumn{2}{|l|}{ PKP Pembulatan } \\
\hline \multicolumn{2}{|l|}{ Pajak Penghasilan Tahun2012 } \\
\hline $50 \%$ & \\
\hline 29.618 .000 & 3.702 .250 \\
\hline
\end{tabular}

Seperti tabel 4.8, pada tabel 4.9 setelah mengetahui jumlah koreksi positif dan koreksi negatif selama tahun 2012, hal selanjutnya ialah menghitung jumlah pajak terhutang tahun 2012. Untuk mengetahui jumlah pajak terhutang tahun 2012 bisa dilihat pada tabel diatas, ditabel terlihat ditahun 2012 perusahaan memperoleh laba fiskal sebesar Rp.53.187.476,- tetapi karena didalam perpajakan memperbolehkan adanya kompensasi kerugian maka jumlah perolehan laba tersebut dikurangi dengan kompensasi kerugian pada tahun 2008-2009 sebesar Rp.11.100.302,- dan Rp.12.343.323,- maka jumlah laba fiskal menjadi Rp. 29.618.851,dan jumlah pajak terhutang tahun 2012 sebesar Rp. 3.702.250,-.

Tabel 4.10 
PT. DBL

Perhitungan Pajak Penghasilan badan sebelum PP 462013

Januari - Juli Th 2013

\begin{tabular}{|c|c|}
\hline Keterangan & $\mathbf{R p}$ \\
\hline Laba (Rugi) Komersial: & 25.120 .941 \\
\hline \multicolumn{2}{|l|}{ Koreksi Positif (Negatif): } \\
\hline Jumlah Koreksi Positif & 39.198 .147 \\
\hline Jumlah Koreksi (Negatif) & $(249.074)$ \\
\hline Laba (Rugi) Pajak (DPP): & 44.595.477 \\
\hline PKP Pembulatan & 44.595.000 \\
\hline \multicolumn{2}{|l|}{ Pajak Penghasilan Tahun 2013} \\
\hline $50 \%$ & \\
\hline $\begin{array}{lll}\mathrm{x} & \mathrm{x} & 44.595 .000\end{array}$ & 5.574 .435 \\
\hline \multicolumn{2}{|l|}{ Pajak Dibaya dimuka } \\
\hline PPh Ps 25 & $(1.234 .080)$ \\
\hline PPh Ps 29 yang Dibayar & 4.340 .355 \\
\hline
\end{tabular}

Tidak seperti ditahun sebelumnya, pada tahun 2013 ini penghitungan pajak terhutang hanya sampai dengan Juli tahun 2013. Setelah mengetahui jumlah koreksi positif dan koreksi negatif yang terdapat pada tabel 4.7 maka hal selanjutnya ialah menghitung jumlah pajak terhutang. Tabel 4.10 ini berisikan ulasan mengenai perhitungan pajak terhutang Januari sampai dengan Juli tahun 2013, Dari tabel diatas terlihat perusahaan memperoleh laba sebesar Rp.44.595.000 dan jumlah pajak terhutang tahun 2013 sebesar Rp.4.340.355.

\section{Besarnya Pajak Terhutang atas Pajak yang Diabayarkan Setelah} adanya "Peraturan Pemerintah Nomor 46 Tahun 2013"

Setelah timbulnya kewajiban pajak baru yang sebabkan oleh adanya Peraturan Pemerintah nomor 46 tahun 2013 maka perusahan pun mengikuti peraturan tersebut dengan membayarkan pajak atas penghasilan tertentu lainnya. Dimana penghasilan atau omzet yang didapat selama satu bulan dikenakan PPh Final dengan tarif 1\% setiap bulannya. Berikut rekap perhitungan pajak perusahaan terkait penghasilan tertentu lainnya atau final $1 \%$. 
Tabel 4.11

Rekap Pajak Penghasilan PPh 4 (2) atas Penghasilan Tertentu

Periode Juli sampai dengan Desember 2013

\begin{tabular}{|l|c|r|c|r|}
\hline \multicolumn{1}{|c|}{ Masa } & Tahun & Penjualan & \multicolumn{1}{c|}{ Tarif } & PPh Terhutang \\
\hline Juli & 2013 & \multicolumn{3}{|c|}{ Tidak Ada Data } \\
\hline Agustus & 2013 & 165.996 .865 & $1 \%$ & 1.659 .969 \\
\hline September & 2013 & 176.143 .855 & $1 \%$ & 1.761 .439 \\
\hline Oktober & 2013 & 175.383 .270 & $1 \%$ & 1.753 .833 \\
\hline Nopember & 2013 & 72.650 .665 & $1 \%$ & 726.507 \\
\hline Desember & 2013 & 73.619 .210 & $1 \%$ & 736.192 \\
\hline \multicolumn{2}{|r|}{ Jumlah } & 663.793 .865 & & 6.637 .940 \\
\hline
\end{tabular}

Sumber : Data diolah Sendiri

Dapat dilihat diatas jumlah penjualan dan $\mathrm{PPh}$ terhutang selama Juli sampai dengan Desember tahun 2013. Setiap penjualan yang didapat dikalikan $1 \%$ untuk mengetahui jumlah pajak terhutang.

Tabel 4.12

Rekap Pajak Penghasilan PPh 4 (2) atas Penghasilan Tertentu Periode Januari sampai dengan Juli 2014

\begin{tabular}{|l|c|c|c|r|}
\hline \multicolumn{1}{|c|}{ Masa } & Tahun & Penjualan & Tarif & PPh Terhutang \\
\hline Januari & 2014 & 155.720 .845 & $1 \%$ & 1.557 .208 \\
\hline Februari & 2014 & 187.144 .053 & $1 \%$ & 1.871 .440 \\
\hline Maret & 2014 & 246.074 .855 & $1 \%$ & 2.460 .748 \\
\hline April & 2014 & 262.734 .220 & $1 \%$ & 2.627 .342 \\
\hline Mei & 2014 & 290.118 .720 & $1 \%$ & 2.901 .187 \\
\hline Juni & 2014 & 261.994 .850 & $1 \%$ & 2.619 .948 \\
\hline Juli & 2014 & 309.417 .242 & $1 \%$ & 3.094 .172 \\
\hline Jumlah & & 1.713 .204 .785 & & 17.132 .045 \\
\hline
\end{tabular}

Sumber : Data diolah sendiri

Dari tabel 4.12 terlihat jumlah pajak yang dikeluarkan perusahaan setelah adanya "Peraturan Pemerintah Nomor 46 tahun 2013" selama 1 periode tahun pajak. 
Berdasarkan penelitian dan informasi melalui bagian Pajak yang peneliti lakukan di PT. DBL, diperoleh data pelaporan dan penyetoran "Pajak Final Pasal 4 ayat 2" atas Penghasilan Tertentu Lainnya yang dilakukan PT. DBL, menunjukan data mengenai pelaporan dan penyetoran PT. DBL pada Juli sampai dengan Desember 2013. Dimana penyetoran dan pelaporan Pajak "Pasal 4(2) atas Penghasilan Tertentu Lainnya" yang PT. DBL lakukan telah sesuai dengan peraturan perpajakan dimana penyetoran dilakukan perusahaan maksimal tanggal 15 pada bulan berikutnya, dan pelaporan paling maksimal pada tanggal 30 bulan berikutnya. Walaupun dibulan November terlihat adanya telat bayar dan telat lapor hal ini tidak menyurutkan PT. DBL untuk tetap tertib administrasi dalam perpajakan.

Dan untuk pada Januari sampai dengan Juli 2014 menunjukan data penyetoran dan pelaporan Pajak Final Pasal 4 ayat 2 atas Penghasilan Tertentu Lainnya yang dilakukan PT. DBL telah sesuai dengan peraturan perpajakan dimana penyetoran dilakukan perusahaan maksimal tanggal 15 pada bulan berikutnya, dan pelaporan paling maksimal pada tanggal 30 bulan berikutnya.

\section{Perbandingan Jumlah Pajak Perusahaan Sebelum dan Sesudah Adanya "Peraturan Pemerintah Nomor 46 Tahun 2013"}

Selama menjalankan kegiatannya, jumlah pajak yang harus dibayarkan oleh perusahaan mengalami kenaikan dan penurunan. Kenaikan serta penurunan jumlah pajak yang harus dibayarkan bervariasi setiap tahun. Untuk mengetahui dan membandingakan berapa jumlah pajak yang dikeluarkan oleh perusahaan sebelum \& sesudah adanya "Peraturan Pemerintah Nomor 46 tahun 2013" dapat dilihat dari data ditabel 4.15, 4.16 dan tabel 4.17:

Tabel 4.15

Pajak Badan PT. DBL Sebelum \& Sesudah adanya "Peraturan Pemerintah Nomor 46 Tahun 2013" 


\begin{tabular}{|c|c|c|c|c|}
\hline Bulan & Tahun & $\begin{array}{c}\text { Penjualan } \\
\text { (Rp) }\end{array}$ & $\begin{array}{c}\text { Jumlah Pajak } \\
\text { Badan } \\
\text { Terhutang }\end{array}$ & \% \\
\hline Jan - Juli & 2011 & 1.237 .500 .000 & - & - \\
\hline Agust - Des & 2011 & & - & \\
\hline Jan - Juli & 2012 & 1.577 .401 .564 & $\mathbf{3 . 7 0 2 . 2 5 0}$ & $\mathbf{0 , 2 3 4}$ \\
\cline { 1 - 3 } Agust - Des & 2012 & 1.196 .280 .559 & $\mathbf{4 . 3 4 0 . 3 5 5}$ & $\mathbf{0 , 3 6 2}$ \\
\hline Jan - Juli & 2013 & \multicolumn{2}{|c|}{} \\
\hline
\end{tabular}

Sumber : PT. DBL

Dari tabel diatas terlihat jumlah pajak perusahaan yang dikeluarkan sebelum adanya "Peraturan Pemerintah Nomor 46 Tahun 2013", jumlah pajak yang dikeluarkan jika dikalikan dengan penjualan kurang dari $1 \%$.

Tabel 4.16

Pajak PPh Pasal 4(2) atas Penghasilan Tertentu Lainnya Tahun 2013 (Juli - Desember )

\begin{tabular}{|l|c|c|c|}
\hline \multicolumn{1}{|c|}{ Bulan } & Penjualan & $\begin{array}{c}\text { Jumlah PPh } \\
\text { Terhutang }\end{array}$ & \% \\
\hline Juli & - & - & - \\
\hline Agustus & 165.996 .865 & 1.659 .969 & $1 \%$ \\
\hline September & 176.143 .855 & 1.761 .439 & $1 \%$ \\
\hline Oktober & 175.383 .270 & 1.753 .833 & $1 \%$ \\
\hline November & 72.650 .665 & 726.507 & $1 \%$ \\
\hline Desember & 73.619 .210 & 736.192 & $1 \%$ \\
\hline Jumlah & $\mathbf{6 6 3 . 7 9 3 . 8 6 5}$ & $\mathbf{6 . 6 3 7 . 9 3 9}$ & \\
\hline
\end{tabular}

Sumber : Data Diolah Sendiri

Tabel 4.17 
Pajak PPh Pasal 4(2) atas Penghasilan Tertentu Lainnya Tahun 2014

(Januari - Juli)

\begin{tabular}{|l|r|c|c|}
\hline \multicolumn{1}{|c|}{ Bulan } & \multicolumn{1}{c|}{ Penjualan } & $\begin{array}{c}\text { Jumlah PPh } \\
\text { Terhutang }\end{array}$ & \% \\
\hline Januari & 155.720 .845 & 1.557 .208 & $1 \%$ \\
\hline Februari & 187.144 .053 & 1.871 .440 & $1 \%$ \\
\hline Maret & 246.074 .855 & 2.460 .748 & $1 \%$ \\
\hline April & 262.734 .220 & 2.627 .342 & $1 \%$ \\
\hline Mei & 290.118 .720 & 2.901 .187 & $1 \%$ \\
\hline Juni & 261.994 .850 & 2.619 .948 & $1 \%$ \\
\hline Juli & 309.417 .242 & 3.094 .172 & $1 \%$ \\
\hline \multicolumn{1}{|c|}{ Jumlah } & $\mathbf{1 . 7 1 3 . 2 0 4 . 7 8 5}$ & $\mathbf{1 7 . 1 3 2 . 0 4 5}$ & \\
\hline
\end{tabular}

Sumber : Data Diolah Sendiri

Dari hasil rekapan pajak diatas terlihat dari Januari tahun 2011 hingga Desember 2012 PT. DBL tidak terhutang pajak badan. Namun, pada saat Januari 2013 terlihat ada perbedaan. Di tahun 2013, terdapat 2 jenis perpajakan yang berbeda, hal ini disebabkan adanya "Peraturan Pemerintah Nomor 46 Tahun 2013" yang mengakibatkan timbulnya kewajiban perpajakan baru dengan tarif sebesar $1 \%$ dari omzet atau peredaran bruto sebulan.

Untuk mengetahui mengetahui $\mathrm{PPh}$ terhutang tersebut dapat dilihat dari tabel4.11 -4.12 dan tabel 4.14 - 4.15 mengenai pajak terhutang selama Juli tahun 2013 sampai dengan Juli tahun 2014. Berikut contoh perhitungan $\mathrm{PPh}$ yang dikenakandari Penghasilan yang berasal dari Usaha yang diterima atau diperoleh Wajib Pajak yang memiliki Peredaran Bruto tertentu dibulan Agustus yaitu :

$$
\begin{aligned}
& \text { Penjualan } 1 \text { Bulan } \mathrm{x} \text { Tarif }=\mathrm{PPh} \text { Terhutang } \\
& =\mathrm{Rp} 165.996 .865,-\mathrm{x} 1 \%=\mathrm{Rp} 1.659 .969,-
\end{aligned}
$$




\section{Pengaruh "Peraturan Pemerintah Nomor 46 Tahun 2013" Terhadap Pajak Perusahaan di PT. DBL}

Untuk mengetahui pengaruh "Peraturan Pemerintah Nomor 46 Tahun 2013" terhadap jumlah pajak perusahaan, dapat dilihat pada tabeldibawah ini :

Tabel 4.18

Rekap Pajak Badan PT. DBL Sebelum \& Sesudah adanya "Peraturan Pemerintah Nomor 46 Tahun 2013"

\begin{tabular}{|c|c|c|c|c|c|}
\hline Bulan & Tahun & Penjualan & $\begin{array}{c}\text { Jumlah Pajak } \\
\text { Badan } \\
\text { Terhutang }\end{array}$ & $\%$ & Keterangan \\
\hline Jan - Juli & 2011 & \multirow{2}{*}{1.237 .500 .000} & \multirow{2}{*}{ A } & \multirow[b]{2}{*}{-} & \multirow[t]{2}{*}{ Sebelum PP 46} \\
\hline Augt - Des & 2011 & & & & \\
\hline Jan - Juli & 2012 & \multirow{2}{*}{1.577 .401 .564} & \multirow{2}{*}{3.702 .250} & \multirow{2}{*}{0,234} & \multirow[t]{2}{*}{ Sebelum PP 46} \\
\hline Augt - Des & 2012 & & & & \\
\hline Jan - Juli & 2013 & 1.196 .280 .559 & 4.340 .355 & 0,362 & Sebelum PP 46 \\
\hline Augt - Des & 2013 & 663.793 .865 & 6.637 .939 & 1,00 & Sesudah PP 46 \\
\hline Jan - Juli & 2014 & 1.713 .204 .785 & 17.132 .045 & 1,00 & Sesudah PP 46 \\
\hline
\end{tabular}

Sumber : PT. DBL

Berdasarkan penelitain dan tabel diatas, dapat disimpulkan adanya pengaruh yang disebabkan oleh "Peraturan Pemerintah Nomor 46 Tahun 2013"terhadap Pajak Perushaan. Sebelum adanya "Peraturan Pemerintah Nomor 46 Tahun 2013"terlihat bahwa perusahaan mengeluarkan pajak pada tahun 2012 hanya sebesar Rp. 3.702.250 dan pada tahun 2013 sampai dengan juli sebesar Rp. 4.340.344. Tetapi setelah timbulnya "Peraturan Pemerintah Nomor 46 Tahun 2013" pajak yang dikeluarkan perusahaan per Agustus sampai dengan Desember 2013 sebesar Rp. 6.637 .939 dan Januari sampai dengan Juli 2014 sebesar Rp. 17.132.045, jumlah ini jauh lebih besar dibandingkan jumlah pajak yang dikeluarkan perusahaan sebelum adanya "Peraturan Pemerintah Nomor 46 Tahun 2013". 


\section{SIMPULAN}

Berdasarkann hasil penelitian, maka dapat disimpulkan :

1. Pengeluaran Pajak perusahaan sebelum \& sesudah penerapan "Peraturan Pemerintah Nomor 46 Tahun 2013" terdapat perbedaan yang cukup besar. Besarnya jumlah pajak yang dibayarkan perusahaan setelah adanya "Peraturan Pemerintah Nomor 46 Tahun 2013" tidaklah sedikit. Para pengusaha kecil beranggapan dengan adanya peraturan terbaru ini menjadi pemindahan dari segi beban pajak, yang semula dipikul oleh pengusaha besar bergeser kepada pengusaha kecil. Namun dalam hal kemudahan administrasi pajak, "Peraturan Pemerintah Nomor 46 tahun 2013" dengn tarif flat 1\% dapat dikatakan lebih efisien dari segi adiministrasi dan tarif bila dibandingkan dengan penggunaan tarif lainnya.

2. Hasil penelitian terlihat ada perbedaan antara pengeluaran pajak perusahaan sebelum dan sesudah penerapan "Peraturan Pemerintah Nomor 46 Tahun 2013”. Hasil penelitian menunjukkan bahwa jumlah pajak badan terhutang sebelum adanya "Peraturan Pemerintah Nomor 46 tahun 2013" sebesar Rp.8.042.605,- dan pajak terhutang sesudh adanya "Peraturan Pemerintah Nomor 46 Tahun 2013" sebesar Rp.23.769.984,. Program pemerintah dengan menambahakan peraturan baru berdampak positif.

3. “Peraturan Pemerintah Nomor 46 Tahun 2013”berpengaruh terhadap besarnya pajak yang dibayarkanoleh perusahaan, dimana apabila nilai omset penjualan mengalami peningkatan maka jumlah pajak yang dibayarkan pun ikut mengalami peningkatan, begitu pula sebaliknya. Bisa dapat dilihat pada hasil penelitian, penjualan sebesar Rp.175.383.270,- pajak terhutang sebesar Rp.1.753.833,- dan penjualan Rp.72.650.665,- pajak terhutang sebesar Rp.726.507,- 


\section{REFERENSI}

Bina Fiskal Indonesia. 2012 . "Modul Pelatihan Pajak Brevet A dan B", Tangerang,

Brotodihrdjo, Santoso. 2014.”Pengantar Ilmu Hukum Pajak”. Bandung: PT. Refika Aditama.

Djuanda Gustian dan Lubis Irwansyah. 2002. "Pelaporan Pajak Penghasilan". Jakarta Edisi Revisi, PT SUN.

Encyclopedia Wikipedia Indonesia. 2009. pada entry "Pajak Penghasilan"

Fakultas Ekonomi Universitas Pamulang. 2013. "Pedoman Penulisan Skripsi”.

Tangerang Selatan. Fakultas Ekonomi Universitas Pamulang.

Google, "Pengertian Organisasi", artikel diakses tanggal 15 September 2014 dari www.organisasi.org.

Gunadi. 2002. "Panduan Komprehensip Pajak Penghasilan". Jakarta: PT. Multi Utama Indojasa.

Judieseno, Rimsky. 2001. "Perpajakan”. Jakarta: PT Gramedia Pustaka Utama.

Kantor Pelayanan Pajak Prata Cilandak, PP no 46 taun 2013. 2013.

Kartosapuerta, G. DkK. 2003. "Koperasi Indonesia” Cetaka keenam. Penerbit rineke Cipta.

Mardiasmo. 2013 “Perpajakan”, Edisi Revisi 2013. Yogyakarta : Andi.

Moh. Nazir. 2011. “Metodelogi Penelitian”. Jakarta: Galia Indonesia.

Republik Indonesia, "Peraturan Menteri Keuangan Nomor 107/PMK.011/2013"

Republik Indonesia, "Peraturan Pemerinatah Nomor 46 Tahun 2013"

Republik Indonesia, "Surat Edaran Dirjen Pajak Nomor SE-42/PJ/2013"

Resmi, Siti. 2009. “Perpajakan: Teori dan Kasus Edisi 5”. Jakarta: Salemba Empat.

Rismawati Sudirman dan Antong Amiruddin. 2012. "Perpajakan Pendekatan Teori dan Praktik”. Malang: Empat Dua. 
Sugiyono. 2012. "Metodelogi Penelitian Kuantitatif” Kualitatif dan $R \& D$. Bandung: Alfabeta.

Sukmadinata Syaodih, Nana. 2011. “Metodelogi Penelitian Pendidikan”. Jakarta: Rosda.

Waluyo. 2013. “Perpajakan Indonesia”. Jakarta: Salemba empat. 